\title{
MEMBANGUN SIKAP SOSIALANAK MELALUI \\ PERMAINAN TRADISIONAL
}

\author{
Oleh \\ Ni Nyoman Mariani \\ (Dosen Jurusan Pendidikan Guru Sekolah Dasar IHDN Denpasar)
}

\begin{abstract}
Traditional games, especially traditional Balinese games have been abandoned, one reason is the rapid development of technology in various aspects of life, one of them is digital games. Traditional games actually have many benefits for children, indirectly children will be stimulated to be creative and very good for the physical and psychological training of children. It is part of the character education process, so the traditional games can be started early. In the traditional games, students are able to build social attitude, such as social ability to work together, compact, have democratic attitude and love attitude environment. social attitude is expected to facilitate or provide opportunities for positive development of children, then they will be able to achieve social development in a mature. On the contrary, if the social environment is less conducive, the social attitude of the children tend to display deviant behavior. For that, the development of a social attitude of children through traditional games is needed.
\end{abstract}

\section{Keywords: Social Attitudes, Traditional Games}

\begin{abstract}
Abstrak
Permainan tradisional khususnya permainan tradisional Bali sudah mulai ditinggalkan, salah satu sebabnya adalah pesatnya perkembangan teknologi dalam berbagai segi kehidupan salah satunya permainan digital. Permainan tradisional sesungguhnya memiliki banyak manfaat bagi anak-anak, secara tidak langsung anak akan dirangsang untuk berkreatifitas, serta sangat baik untuk melatih fisik dan psikis anak. Hal tersebut merupakan bagian dari proses pendidikan karakter, maka permaian tradisional dibangun kembali dapat dimulai sejak dini.Pada permainan tradisional mampu membangun sikapsosial anak, seperti kemampuan sosial untuk bekerja sama, kompak, sikap demokratis dan sikap mencintai lingkungan. sikap sosial yang dimaksud diharapkan mampu memfasilitasi atau memberikan peluang terhadap perkembangan anak secara positif, maka anak akan dapat mencapai perkembangan sosial secara matang. Namun sebaliknya, apabila lingkungan sosial itu kurang kondusif, maka sikap sosial anak cenderung menampilkan perilaku yang menyimpang. Untuk itu, pengembangan sikap sosial anak melalui permainan tradisional sangat diperlukan.
\end{abstract}

Kata Kunci : Sikap Sosial, Permainan Tradisional

I. PENDAHULUAN

Permainan modern dengan berbagai ke-elektronikannya telah menjadi prioritas untuk anak Indonesia saat ini. Permaianan modern ini telah mampu menggusur keberadaan dari permainan tradisional 
yang telah menjadi budaya. Kemajuan teknologi telah membawa perubahan dalam berbagai hal termasuk dalam hal bermain. Perubahan dalam bermain ini lebih mengacu pada permainan elektronik seperti Playstation, dan Game online dan masih banyak lagi yang lainnya. Saat ini permainan modern seperti ini yang digemari anak-anak. Permainan modern ini mampu membuat anak berpikir kreatif karena game yang ada sangat beragam. Dampak negatifnya interaksi sosial anak sangat kurang, bahkan terkadang dalam game termuat unsur kekerasan.

Pada dasarnya dunia anak-anak adalah dunia bermain. Bermain adalah kegiatan yang sangat penting dan menyenangkan dalam proses belajar anak. Melalui bermain anak akan didorong untuk bereksperimen dan tumbuh dengan baik dalam kehidupan. Permainan tradisional mempunyai ragam bentuk dan variasi yang begitu banyak. Permainan tradisional cenderung memanfaatkan alat atau fasilitas di lingkungan kita tanpa harus membelinya sehingga perlu daya imajinasi dan kreativitas yang tinggi. Permainan tradisional dominan melibatkan pemain yang relatif banyak. Tidak mengherankan, kalau dilihat hampir semua permainan rakyat begitu banyak anggotanya. Sebab, selain mendahulukan faktor kesenangan bersama, permainan ini juga mempunyai maksud lebih pada pendalaman kemampuan interaksi antar pemain.

Selain itu permainan tradisional juga sarat dengan nilai-nilai luhur dan pesan-pesan moral tertentu seperti nilainilai kebersamaan, kejujuran, tanggung jawab, sikap lapang dada (kalau kalah), dorongan berprestasi, dan taat pada aturan. Semua itu didapatkan kalau si pemain benar-benar menghayati, menikmati, dan mengerti intisari dari permainan tersebut. Orang tua yang baik pasti mengetahui bagaimana menanamkan nilai-nilai positif pada perkembangan anak-anaknya dalam bentuk permainan tradisional sebagai alat untuk menentukan karakter anak ke depannya.Selain itu semua yang terpenting adalah bagaimana peran kita untuk turut serta mengembalikan dan mengenalkan permainan tradisional terhadap generasi muda Indonesia atau memodernkan permainan anak tradisional.

Banyak manfaat yang dapat diambil dari permainan tradisional misalkan sosialisasi dengan orang lain akan baik, dalam bermain kelompok mereka juga harus mengatur strategi, berkomunikasi dan bekerja sama dalam bermain. Ada banyak permainan tradisional seperti; curik-curik, meong-meonyan, juru pencar, pul sinoge, pul kidu-kidu, penyu metaluh, kelik-kelikan, gale-gule, jaksajaksaan, congklak, lompat tali cici putri dan masih banyak lagi yang lainnya. Hal ini menunjukkan bahwa permainan tradisional Bali sangat melimpah. Tapi kenyataan yang ada di masyarakat sekarang permainan tradisional sangat jarang dimainkan dengan berbagai alasan. Dalam melakukan permainan, komunikasi sudah barang tentu menjadi pioritas utama dalam bermain. Karena komunikasi merupakan proses penyampaian pesan berupa lambang-lambang yang mengandung arti lewat saluran tertentu dari komunikator kepada komunikan (Jendra, 2000:34). Dengan adanya suatu komunikasi yang terjalin dengan baik 
dalam suatu permainan, maka akan menciptakan suasana yang menyenangkan antar anggotanya.

\section{PEMBAHASAN}

Dalam Psikologi Perkembangan (Ahmadi,2005: 105-106) permainan adalah suatu perbuatan yang megandung keasyikan dan dilakukan atas kehendak diri sendiri, bebas tanpa paksaan dengan tujuan untuk memproleh kesenangan pada waktu mengadakan kegiatan tersebut. Karakteristik bermain yaitu : (a) sifatnya bebas (tidak terlalu terikat oleh syarat), (b) tidak berorientasi hasil, tujuannya hanya kesenangan dan bermain, (c) hasilnya (kesenangan) ada dalam kegiatan itu, (d) hakikatnya untuk anak.

Permainan tradisional merupakan salah satu unsur budaya bangsa yang banyak tersebar di berbagai penjuru nusantara terutama pada masyarakat pedesaan yang sulit untuk menemukan permainan modern. Permainan tradisional sudah hampirpunah terlupakan danterganti dengan permainan modern. Sebaiknya ada upaya dari orang tua atau dewasa yang pernah mengalami fase bermain, untuk memperkenalkan dan melestarikan kembali permainan-permainan tersebut, karena permainan tersebut sangat besar pengaruhnya terhadap perkembangan anak-anak.

Permainan tradisional sering disebut juga dengan permainan rakyat, merupakan permainan yang tumbuh dan berkembang pada masa lalu terutama tumbuh dimasyarakat pedesaan. Permainan tradisional tumbuh dan berkembang berdasarkan kebutuhan masyarakat setempat, kebanyakan permainan tradisional dipengaruhi oleh alam lingkungannya, oleh karena itu permainan tradisional selalu menarik, menghibur sesuai dengan kondisi saat itu.

Oka (dalam Taro, 2002:3) mengatakan bahwa permaian tradisional Bali adalah aktifitas budaya dalam bentuk permainan yang terdiri dari unsur-unsur gerak, seni, nilai lokal dan budaya yang tersebar dalam masyarakat, hal ini sejalan dengan tujuan permainan tradisional Bali pada pendidikan yakni memacing pertumbuhan dan perkembangan jasmani, mental, emosional dan sosial budaya yang selaras dalam upaya membentuk serta mengembangkan kemampuan dan kepribadian yang berwawasan lingkungan.

Taro (2002:2) menyatakan bahwa sementara ini di Bali tercatat memiliki lebih dari 150 jenis permainan tradisional Bali. Jika jenis-jenis permainan itu diperbandingkan dengan permainanpermainan lain yang tersebar dikawasan Asia Tenggara, maka terdapat banyak persamaan dan perbedaan-perbedaan. Perbedaan-perbedaan itu merupakan variasi, terutama dalam asfek fisik dan prilaku. Jangankan perbedaan-perbedaan variasi antara permainan tradisional Bali dengan Thailand atau Jawa, permainan antara desa dengan desa yang lainnya di Bali pun sering ditemukan perbedaan variasi tersebut. Hal itu mencerminkan adanya kreasi lokal yang dapat memperkaya khasanah budaya Nasional maupun budaya daerah khusunya Bali. Adapun ciri-ciri permainan tradisional di Bali adalah (1) mudah dimainkan, (2) memiliki seperangkat aturan, (3) kadangkadang diiringi lagu, (4) sarana dan prasarana tidak terlalu mengikat, (5) kaya variasi dan (6) fleksibel. 
Sikap sosial sangat penting dikembangkan kerena beberapa hal yang mendasar yang mendorong pentingnya pengembangan sikap sosial emosional tersebut. Semua jenis permainan tradisional adalah permainan yang bersifat sosial. Salah satu fungsi permainan rakyat tersebut adalah untuk mengadakan komunikasi, baik dengan lingkungan alam maupun lingkungan sosialnya. Komunikasi itu sendiri dimaksudkan untuk menciptakan rasa kebersamaan diantara kelompok orang yang terlibat di dalam permainan tersebut. Dalam masyarakat Bali nilai kesetiaan ini bahkan memiliki nilai yang sangat tinggi. Kesetiaan bahkan sering diartikan sebagai kebenaran. Dalam ajaran Agama Hindu ada disebutkan satyam eva jayate yang berarti bahwa kesetiaan atau kebenaran senantiasa jaya (menang).

Selama mengamati proses permainan, dalam permainan ini adalah pengamatan terhadap peningkatan sikap sosial anak. Dengan demikian, diharapkan terjadinya perubahan-perubahan perilaku berupa kemampuan-kemampuan dalam hal pengatahuan sosial dan sikap sosial anak. Sikap sosial yang terlihat pada saat permainan dan selesai permainan yang dapat diamati yakni (1) anak belajar bergaul dengan anak yang lain, dengan adanya interaksi kepada teman-teman bermainnya anak belajar mengembangkan hubungan dengan anak lain yang dapat menghasilkan dampak positif dari anak lain dalam lingkungan masyarakat yang lebih luar dari lingkungan keluarganya. (2) dapat mengembangkan perasaan positif dalam hubungan dengan lingkungan, dan perasaan kasih sayang terhadap temantemannya dan alam yang ada di sekitarnya.
(3) anak-anak bisa mengendalikan dirinya, sehingga bertingkah laku sesuai dengan tuntutan dimasyarakat. (4) dari permainan tradisional tersebut setiap anak dapat belajar memberi, membagi dan memproleh kasih sayang antara anak yang satu dengan anak yang lainnya agar dapat hidup secara harmonis, aman, bahagia dilingkungannya dan juga di masyarakat. Oleh karena itu anak yang memiliki kemampuan bersosialisasi yang tinggi dapat menentukan anak menunjukan rasa percaya diri kepada teman, guru, keluarga dan masyarakat. Semakin banyak anak menunjukan rasa percaya diri, maka banyak pengalaman yang didapat oleh anak tersebut.

Permainan tradisional yang sifatnya beregu ataupun tunggal dapat melatih anak memiliki rasa sosial yang tinggi sehingga sifat egois anak setikitnya dapat dihindari. Dalam setiap permainan ada menang dan kalah, hal ini menuntut anak untuk disiplin, jujur dan sportif mengakui kemenangan lawan bermainnya. Serta melalui bermain, anak akan mudah bergaul dengan temantemannya, sehingga mendukung anak untuk dapat berprilaku sosial sesuai dengan aturan dalam kehidupan bermasyarakat. Dengan demikian permainan tradisional secara jelas bukanlah permainan yang hanya sekedar untuk mengisi waktu luang guna menghilangkan bosan, tetapi suatu kegiatan yang tidak sedikit artinya bagi pendidikan, pembinaan, dan perkembangan anak dalam menuju kedewasan yang kelak mereka bawa dalam lingkungan masyarakat.

\section{SIMPULAN}

Permainan tradisional yang sudah ada dari sejak dulu merupakan hasil 
dari proses kebudayaan manusia zaman dahulu yang masih kental dengan nilainilai kearifan lokal. Meskipun sudah tua, tenyata permainan tradisional memiliki peran edukasi terutama terkait dengan bagaimana mengembangan sikap sosial anak yang sangat menusiawi bagi proses belajar seorang individu, terutama anak usia dini. Dikatakan demikian, karena secara ilmiah permainan tradisional mampu menstimulasi berbagai aspekaspek perkembangan anak yaitu: motorik, kognitif, emosi, bahasa, sosial, spiritual, ekologis, dan nilai-nilai/moral.

\section{DAFTAR PUSTAKA}

Ahmadi, Abu. 1991. Psikologi Perkembangan. Jakarta: Rineka Cipta

Adisusilo J.R., Sutarjo. 2012. Pembelajaran Nilai-Karakter Konstruktivisme dan VCT sebagai Inovasi Pendekatan Pembelajaran Afektif. Jakarta: PT Rajagrafindo Persada

Gautama, Wayan Budha. 2009. Kamus Bahasa Bali (Bali-Indonesia). Surabaya: Paramita

Handayani, Dewi, Dantes, N, Lasmawan, W. 2013. Penerapan Permainan Tradisional Meong-meong untuk Perkembangan Sikap Sosial Anak Kelompok B Taman Kanakkanak Astiti Dharma Penatih Denpasar. e-Journal: P r o g r a m Pascasarjana Universitas endidikan Ganesha Jurusan Pendidikan Dasar (Vol.3).

Jones, Pip. 2010. Pengantar Teori-teori Sosial (Dari Teori Fungsionalisme Hingga Post-Modernisme). Jakarta: Yayasan Pustaka Obor Indonesia
Kemendiknas. 2011. Panduan Pelaksanaan Pendidikan

Karakter. Badan Penelitian dan Pengembangan Pusat Kurikulum dan Perbukuan. Jakarta

Kerta Adhi, Made. 2014. Model Pendidikan Karakter Berbasis Mendongeng. Jurnal Santiaji Pendidikan; Vol 4 (1).

Listyarti, Retno. 2012. Pendidikan Karakter Dalam Metode Aktif, Inovatif, dan Kreatif. Esensi

Mahfud, Choirul. 2008. Pendidikan Multi Kultural. Yogyakarta. Pustaka Pelajar

Primayoga Arya, Putu Adiya. 2015. Revitalisasi Permainan Tradisional Bali Sebagai Bagian dari Atraksi Wisata Budaya di Kota Denpasar. Jumpa Vol. 1 No. 2

Sulistyowati, Endah. 2012. Implementasi Kurikulum Pendidikan Karakter. Yogyakarta: PT. Citra Aji Parama

Titib, I Made. 2003. Menumbuhkembangkan Pendidikan Budhi Pekerti Pada Anak (Perspektif Agama Hindu). Bandung: Ganeca Exact

Taro, Made. 2002. Bunga Rampai Permainan Tradisional. Dinas Pendidikan dan Provinsi Bali Proyek Peningkatan Mutu.

Taro, Made. 2015. Dari Tok Pitu sampai Tok Lati Kancing. Denpasar: Amada Press 